\title{
The Concept of "Generations" of Human Rights and the Right to Benefit from the Common Heritage of Mankind with Reference to Extraterrestrial Realms
}

\author{
By Marjoleine Y. A. Zieck
}

\section{Introduction}

In the seventies a new category of human rights was introduced and given the name of "third generation" or "solidarity" rights. The name and contents of this category were inspired by the rallying cry "freedom, equality and brotherhood" (or solidarity) of the French Revolution. 1 The already existing human rights, on the one hand the civil and political rights and on the other hand the economic, social and cultural rights thought to exemplify freedom and equality respectively 2 , became henceforth known as the first and second generations of human rights.

As time went by, the third generation of human rights multiplied. More and more claims and aspirations were judged to be human rights 3 and as such were given a place in this new category. The category concerned thus got increasingly the character of a residual category of human rights consisting of miscellaneous claims, ranging from the right to peace and the right to be different to the right to share in the benefits of the common heritage of mankind. Although the distinct character of the first and the second generations of human rights is reasonably clear, such is consequently not the case as regards the third generation of human rights.

1 Cf. Alston, P., A Third Generation of Solidarity Rights: Progressive Development or Obfuscation of Intemational Human Rights Law?, 29 Netherlands Intemational Law Review (1982), p. 318; Vasak, $K$., Pour une troisième génération de droits de l'homme, in Swinarski, $C$. (ed.), Studies and essays on intemational humanitarian law and Red Cross principles in honour of Jan Pictet, Geneva / The Hague, 1984, pp. 838, 839.

2 Vasak, 1984, op. cit. supra, p. 839.

3 Cf. Alston, P., Conjuring Up New Human Rights: A Proposal for Quality Control, 78 American Journal of Intemational Law (1984), who identifies several "inventors". Alston qualifies the manner in which the proliferation of new rights is achieved as haphazard and almost anarchic, $p$. 607. 
When the various rights which currently make up this third generation are analyzed, some such rights, such as the right to be different ${ }^{4}$, seem better suited a place among the rights of the first two generations, while others rightly seem to be kept outside the confines of these vested categories. Not so, however, because they would be more sophisticated that the first and second generation human rights, although admittance should be made of the fact that the terminology involved unfortunately warrants such an inference, but simply because they operate altogether at another level than the rights of the first and second generations, which have explicit functions within national societies.

A feature which the third generation rights have in common is that they operate at the international level within the international community. Since the rights in question appear to serve different purposes within that community, clarification is obtained by dividing the various third generation rights into two different categories. The first category would consist of those rights of the third generation which function as ordering principles of the international society itself. Three such rights - the right to peace, the right to self-determination and the right to natural wealth and resources - will be analyzed in this paper under the heading of third generation rights. The keyword of the order which is to result from the rights referred to is formal equality of the constituent parts of the international society, the states. The second category of rights (taken from the original third generation), which will henceforth be termed fourth generation rights, is quite different in character from the third generation rights referred to above. Although the rights of the fourth generation operate equally at the level of the international society, their aim is not mere formal equality of states.

With the increment of states upon decolonization, the enormous disparities in development, wealth and power in the world came clearly to the fore. These disparities existed admittedly before the states concerned attained independent statehood, but independence enabled these "new" states to voice these disparities with matching claims (such as those in favour of the establishment of a new international economic order), through appropriate international channels, such as the U.N. General Assembly. The rights of the fourth generation are the result of the perception on the part of the "new" states that formal equality alone will not lead to or induce a substantial change in these disparities. With the rights of the fourth generation, such as the right to benefit from the common heritage of mankind and the right to development, the concept of formal equality is surpassed in favour of a concept of material equality.

The classification of the various human rights into generations presented so far, in particular the introduction of a fourth one, is based on the assumption that the rights of respec-

4 UNESCO Declaration on Race and Racial Prejudice of 27 November 1978, UNESCO Doc 20 C/3/1.1/2; cf. note 27. 
tively the first and third generation are congenial and that a similar congeniality exists between the second and fourth generation rights. In order to be able to demonstrate the parallels alluded to, I will start this paper with sketching briefly the distinguishing features of the first and second generations of human rights and the three third generation rights mentioned above. Subsequently the - fourth generation - right to benefit from the common heritage of mankind will be analyzed in part two of this paper. This analysis is not only intended to exemplify the distinct character of the fourth generation but also to refute an important objection to solidarity rights in general. This objection consists of the complaint that these rights lack a precise object and are thus incapable of producing definite obligations. A result of this lack of definiteness would be that these rights cannot be judicially enforced.5

The right to benefit from the common heritage of mankind which will be discussed is the right such as is formulated with reference to outer space. Inthe Agreement Governing the Activities of States on the Moon and other Celestial Bodies6, which was adopted in 1979, the moon and its natural resources were declared to be the common heritage of mankind. This treaty entered into force in 1984. The states parties to this treaty undertook to equitably share the benefits deriving from exploitation of the lunar common heritage.

The treaty obligation referred to implies several convictions on the part of the states parties concerned. First of all, by ratifying this treaty the various states acknowledged the possibility of determining the meaning of "equitable sharing". This acknowledgment entails belief in the possibility of reaching a rational judgment on distribution, and in particular, in virtue of the addition of the adjective "equitable", on distributive justice.

The fact that the states parties to the Moon Treaty bound themselves to have the share-out of future benefits from exploitation of the moon's natural resources governed by a just distributional system releases the present writer from the task to answer the usual preliminary question as to why one, or rather, why states should commit themselves to moral reasoning and moral behaviour in the first place, instead of practising Machiavellian politics. As it is, the states concerned rendered this question superfluous simply by ratifying the treaty concerned. The act of ratification "just" leaves the question of the meaning of equitable sharing to be answered.

5 "A classical objection to the third generation of rights, which has also been made in relation to social rights, is that they cannot be judicially enforced. They lack a precise object and their realization is dependent upon prevailing economic circumstances." Flinterman, $C$., Three Generations of Human Rights, in Berting, $J$. et al. (eds.), Human Rights in a Pluralist World, Individuals and Collectivities, Westport 1990, p. 79.

6 Adopted by the U.N. General Assembly, Res. 34/68 on 5 December 1979. Opened for signature on 18 December 1979. Entry into force on 11 July 1984. Parties: Australia, Austria, Chile, Netherlands, Pakistan, Philippines and Uruguay. Hereinafter cited as the Moon Treaty. 
At this point I would like to introduce some aspects of John Rawls' theory of justice. ${ }^{7}$ Rawls' theory is a modern and generalized version of the classical contract theories of society. ${ }^{8}$ Rawls introduces the device of a hypothetical "original position" to identify principles of justice for the basic structure of society which are to function as a standard whereby its distributive aspects are to be assessed. 9 In the present paper this method of arriving at the blue-print of society will be applied to non-terrestrial realms. Since states parties to the Moon Treaty manoeuvred themselves into a position wherein they are, sooner or later, bound to determine what constitutes equitable sharing, Rawls' procedure, which is in part a theory of rational choice, might prove to be a useful tool of analysis.

\section{Part One}

\section{The First Generation}

The first generation of human rights, still better known as the civil and political rights, can be characterized by the denominators of abstention by the state and participation of its subjects in society on the basis of formal equality.

The rights concerned seek to ensure a state-free domain as it were, in which people are free from interference by the state. 10 The following rights which are taken from the International Covenant on Civil and Political Rights11 illustrate this feature of abstention: the right not to be arbitrarily deprived of one's life; the right not to be subjected to torture or to cruel, inhuman or degrading treatment or punishment (in particular not to medical or scientific experimentation without one's consent); the right not to be held in slavery or in servitude; the right not to be subjected to arbitrary arrest or detention; the right not to be imprisoned on the ground of inability to fulfil a contractual obligation; the freedom to leave any country, including one's own; the right not to be arbitrarily denied entrance to one's

7 The theory referred to is expounded in Rawls, J., A Theory of Justice, Oxford 1972.

8 The acjective "classical" refers to the contract theories of society by philosophers as Hobbes, Locke, Rousseau and Kant.

9 See especially paragraph 12 of this paper.

10 Cf. Flinterman, 1990, op. cit. supra, p. 76; and Vasak, 1984, op. cit. supra, p. 838: "La première génération, celle de droits civils et politiques, contient des droits-attributs de la personne humaine, droits qui sont, pour l'essentiel, opposables à l'Etat dont ils supposent d'abord une attitude d'abstention pour qu'ils puissent être respectés." (emphasis added.)

11 Adopted by the U.N. General Assembly on 16 December 1966. Opened for signature on 19 December 1966. Entry into force on 23 March 1976. U.N. Treaty Series, vol. 999, p. 171. Hereinafter cited as the Political Covenant. 
country; the right not to be subjected to arbitrary or unlawful interference with one's privacy, family, home or correspondence; the right to freedom of thought, conscience and religion; the right to hold opinions without interference 12 etc.

The obligation not to interfere is one which is incumbent on the individual state not only as regards its citizens but generally as regards persons who find themselves on the territory of the state concerned and are subject to its jurisdiction. 13 The following provision of the Political Covenant underlines in general terms the obligation not to encroach on the zone of freedom which is created by the various rights referred to above:

"Nothing in the present Covenant may be interpreted as implying for any State, group or person any right to engage in any activity or perform any act aimed at the destruction of any of the rights and freedoms recognized herein or at their limitation to a greater extent than is provided for in the present Covenant." 14

Although the International Covenant on Economic, Social and Cultural Rights 15 contains a similar provision, this clause assumes a different meaning in that Covenant, due to the different objectives of that treaty as compared to those of the Political Covenant. That is to say, not only the objectives of the two Covenants differ, but the nature of the legal obligations which they contain as well 16 and consequently the meaning of the article quoted.

The second distinguishing characteristic of first generation human rights is the emphasis on participation of people in society on the basis of formal equality. A clear indication of this emphasis is the premiselike provision that all should be acknowledged to be human persons with, as a corollary, equal rights. The right to recognition everywhere as a person before the law 17 and the provision that all persons shall be equal before the courts, tribunals 18 and the

12 Articles 6 par. 1; 7; 8 par. 1 and par. 2; 9 par. 1;11;12 par. 2 and par. 4; 17 par. 1; 18 par. 1, 19 par. 1 respectively.

13 Art. 2 par. 1.

14 Art. 5 par. 1.

15 Adopted by the U.N. General Assembly on 16 December 1966. Opened for signature on 19 December 1966. Entry into force on 3 January 1976. U.N. Treaty Series, vol. 993, p. 3. Hereinafter cited as the Social Covenant.

16 Cf. Goodwin-Gill, G. S., Obligations of Conduct and Result, in Alston, P. / Tomasevski, K. (eds.), The Right to Food, Geneva / The Hague 1984, p. 111 et seq.

17 Art. 16.

18 Art. 14 par. 1. Cf. also art. 10 par. 1: "All persons deprived of their liberty shall be treated with humanity and with respect for the inherent dignity of the human person." Cf. also art. 24 par. 3: "Every child has the right to acquire a nationality." 
law ${ }^{19}$ not only reiterate but also substantiate this feature of formal equality. 20 The participatory aspect of the first generation rights might be inferred from the following rights: the right of peaceful assembly; the right to freedom of association with others; the right to form and join trade unions; the right to take part in the conduct of public affairs; the right to vote and to be elected at periodic elections and the right to have access, on general terms of equality, to public service in one's country. 21

Some rights which are labelled as social, economic or cultural rights in virtue of being codified in the Social Covenant might equally be considered as, strictly speaking, belonging to this first generation as they share with the rights from the Political Covenant mentioned above, likewise the emphasis on abstention or participation such as, for instance, the right to take part in cultural life. 22

\section{The Second Generation}

The second generation of human rights consists of economic, social and cultural rights. The common denominator of these rights is material equality. The second generation rights are dynamic in the sense that they demand action on the part of the state in particular as regards its distributive policies. These rights aim at (re)distribution of wealth in an equitable way and as such acknowledge the fundamental premise of all human rights that all human beings are equal with equal entitlements. The rights concerned, however, expand this premise of formal equality, which although a sine qua non does not of itself give rise to a redress of unequal initial positions or to equal opportunities and a certain level of wellbeing for all, to one which does comprise substantial equality as well. Berting describes the essence of the economic, social and cultural rights as follows:

"They are the expression of the acknowledgment that measures have to be taken to remove traditional social barriers to the realization of equal opportunities for everyone and to redress un just inequalities flowing from the outcomes of exchange relationships in the market."

19 Art. 26

20 Cf. art. 2 par. 1 and art. 3; see also the Intemational Convention on the Elimination of All Forms of Racial Discrimination which was adopted by the U.N. General Assembly, Res. 2106 (XX) on 21 December 1965. Opened for signature on 7 March 1966. Entry into force on 4 January 1969. U.N. Treaty Series, vol. 660, p. 195.

21 Respectively articles $21 ; 22$ par. 1 and 25, Political Covenant.

22 Art. 15 sub a, Social Covenant. 
"The social and economic rights as material rights are related to redistribution of commodities and opportunities in society and imply the duty and responsibility of the state to satisfy citizen's needs ..."23

These rights are, in short, codified demands on the state for social change and require state intervention for their realization. The following rights which are taken from the Social Covenant illustrate these demands: the right to work safeguarded by the state; the right to the enjoyment of just and favourable conditions of work (these conditions consist inter alia of renumeration which provides all workers with a decent living for themselves and their families, and of rest, leisure and reasonable limitation of working hours and periodic holidays with pay); the right to social security, including social insurance; the right to an adequate standard of living, including adequate food, clothing and housing, and to the continuous improvement of living conditions; the right to be free from hunger (to be secured by the state by means of improving methods of production, conservation and distribution of food); the right to the enjoyment of the highest attainable standard of physical and mental health; and the right to education. 24

All these and similar rights assume a certain kind of society. Without pursuing the question what blue-print of society is at the root of the various rights of the second generation, it is obvious that the society implied could hardly be an untrammeled capitalist society such as the classical 19th century western night-watchman state. Whether this blue-print is a welfare state, a socialistic state or otherwise, the states parties to the Social Covenant undertook to progressively achieve it. 25

\section{The Third Generation}

The third generation of human rights consists of various rights. An inventory of the rights which appear to be labelled third generation rights so far might comprise any of the following: the right to development; the right to exist; the right to (international) peace and security; the right to communicate; the right to be different; the right to a satisfactory or healthy (or safe or decent or pure) and balanced environment; the right to benefit from the common heritage of mankind; the right to humanitarian assistance; the right to self-determination; the right to utilization of the natural wealth and resources of one's native country and the right to food. 26

23 Berting, J., Societal Change, Human Rights and the Welfare State in Europa, in Berting, 1990, op. cit. supra, p. 198.

24 Respectively articles 6 par. 1; 7; 9; 11 par. 1 and 2; 12 par. $1 ; 13$.

25 Art. 2 par. 1.

26 UNESCO Declaration on Race and Racial Prejudice of 27 November 1978; Universal Declaration of the Rights of Peoples of 4 July 1976, Algiers (printed in Crawford, J. (ed.), The Rights of 
It is hardly possible to find a common denominator for this heterogenous group of rights, of which at least one, the right to be different, appears, prima facie at least, to be a first generation human right. 27 Omitting the right to be different, however, a first common characteristic which might be discerned is that these rights are not directed to a single state. In contradistinction to the first and second generations of human rights, these third generation rights seem not to address one's government but the state-community instead. Appeals for humanitarian assistance in case of natural disasters illustrate this last point vividly.

I would like to elaborate the thesis that some of the above-mentioned third generation rights are similar to first generation rights in that they share with the latter the denominators of abstention and participation on the basis of formal equality. The distinguishing characteristic which sets them apart as distinct categories, however, is the level at which they operate: the first generation rights have a distinct function at the national level as first order principles of the national system and the third generation rights at the international level as first order principles regarding the organizational basis of the international system. I would like to illustrate this point by examining a few rights of the ones enumerated above: the right to peace, the right to self-determination and the right to natural wealth and resources respectively.

Peoples, Oxford 1988; U.N. G.A. Declaration on the Right to Development of 4 December 1986 (41/128); U.N. G.A. Declaration on the Preparation of Societies for Life in Peace of 15 December 1978 (33/73); U.N. G.A. Declaration on the Rights of Peoples to Peace of 12 November 1984 (39/11); cf. also the Universal Declaration of the Rights of Peoples, adopted by scholars and publicists on 4 July 1976 (printed in Crawford, 1988, op. cit. supra, p. 187 et seq.); Vasak, K., A 30-year struggle, the sustained efforts to give force of law to the Universal Declaration of Human Rights, The UNESCO Courier, November 1977, p. 29; Vasak, 1984, op. cit. supra, p. 840; Alston, 1982, op. cit. supra, pp. 307, 308; Flinterman, 1990, op. cit. supra, p. 77; Paul Gormley, W., The Right to a Safe and Decent Environment, 28 Indian Journal of International Law (1988), p. 1 et seq.; Crawford, J., The Rights of Peoples: "Peoples" or "Governments"?, in Crawford, 1988, op. cit. supra, pp. 56, 57; Brunnée, J., "Common Interest" - Echoes from an Empty Shell? Some Thoughts on Common Interest and International Environmental Law, 49 Zeitschrift für ausländisches und öffentliches Recht und Völkerrecht (1989), pp. 797, 799.

27 UNESCO Declaration on Race and Racial Prejudice of 27 November 1978: Art. 1 par. 1: "All human beings belong to a single species and are descended from a common stock. They are bom equal in dignity and rights and all form an integral part of humanity". Art. 2 par. 2: "All individuals and groups have the right to be different, to consider themselves as different and to be regarded as such. However, the diversity of life styles and the right to be different may not, in any circumstances, serve as a pretext for racial prejudice; they may not justify either in law or in fact any discriminatory practice whatsoever, nor provide a ground for the policy of apartheid, which is the extreme form of racism". Art. 2 par. 1: "Any theory which involves the claim that racial or ethnic groups are inherently superior or inferior, thus implying that some would be entitled to dominate or eliminate others, presumed to be inferior, or which bases value judgments on racial differentiation, has no scientific foundation and is contrary to the moral and ethical principles of humanity" etc. Cf. also note 4 and par. 1 of this paper. 
These rights are, in comparison with the other solidarity rights, the older and more generally accepted rights of the series mentioned. Some scholars would even go so far as to qualify the right to self-determination, for instance, as belonging to the body of jus cogens norms, the heavy duty category of international legal norms.

These three rights all share the assumption of the nation-state. The right to peace found its expression in the outlawry of aggressive wars in the relations of states, the right of selfdetermination historically assumed the shape of national states acquiring independence and the right to one's natural resources equally refers to the boundaries of the national state in the form of permanent sovereignty over natural resources.

\section{The Right to Peace}

The right to peace can be considered the corollary or counterpart of the contemporary obligation of states not to resort to war for the solution of international controversies. The prohibition of the use of force in international relations is considered to be a peremptory one.28

The efforts to outlaw aggressive wars date back to 1919 when the Covenant of the League of Nations placed certain limitations upon resort to war 29 and to 1928 when the General Treaty for the Renunciation of War as an Instrument of National Policy (otherwise known as the Briand Kellogg Pact) 30 was signed. The contracting parties to this Pact condemned recourse to war for the solution of international controversies and renounced it as an instrument of national policy in their relations with one another.31 In a similar vein, article 2 paragraph 4 of the U.N. Charter provides:

"All Members shall refrain in their international relations from the threat or use of force against the territorial integrity or political independence of any state ..."

Article 2 par. 4 applies to military or armed force, regardless of whether or not it constitutes a technical state of war. 32 The U.N. General Assembly confirmed this interpretation by defining aggression as the use of armed force by a state, regardless of a declaration of war,

28 Cf. inter alia, Ronzitti, N., Use of Force, Jus Cogens and State Consent, in Cassese, A. (ed.), The Current Legal Regulation of the Use of Force, Dordrecht 1986 I, p. 149 et seq.

29 Cf. art. 12 par. 1 of the Covenant.

30 League of Nations - Treaty Series, vol. XCIV, no. 2137.

31 Art. 1 of the Pact.

32 Cf. Röling, B. V. A., The ban on the use of force and the U.N. Charter, in Cassese, $1986 \mathrm{I}$, op. cit. supra, p. 3 et seq. 
against the sovereignty, territorial integrity or political independence of another state, in the 1974 Resolution on the Definition of Aggression.33

The various duties to which the general prohibition on the use of force gives rise were specified in the General Assembly Declaration on Principles of International Law concerning Friendly Relations and Co-operation among States in accordance with the Charter of the United Nations 34 of 1970 . The first principle of this declaration repeats in almost identical words the provision of article 2 paragraph 4 of the Charter and is followed by a series of definite obligations of states, such as the duty to refrain from propaganda for wars of aggression; the duty to refrain from the threat or use of force to violate the existing boundaries of another state; the duty to refrain from acts of reprisal involving the use of force; the duty to refrain from organizing or encouraging the organization of irregular forces or armed bands for incursion into the territory of another state, etc.

The international obligation to refrain from aggression or the use of force was confirmed earlier by the International Court of Justice in the Corfu Channel Case, in which the Court considered the British "Operation Retail" in Albanian territorial waters unjustified:

"The Court can only regard the alleged right of intervention as the manifestation of a policy of force ... and such as cannot, whatever be the present defects in international organization, find a place in international law."35

A more recent judgment of the International Court of Justice to the same effect can be found in the case concerning military and paramilitary activities in and against Nicaragua (Nicaragua v. United States of America; Merits). 36

The wordings of the prohibition on the use of force and the specific obligation to refrain from acts which are understood to be entailed by it seem to imply that the right to peace which might be deduced from them is primarily a right of states, that is, they benefit from the duty of abstention from aggression by other states. 37 Although "state" is just shorthand

33 United Nations G.A. Res. 3314 (XXIX) of 14 December 1974.

34 United Nations G.A. Res. 2625 (XXV) of 24 October 1970.

35 I.C.J. Reports of Judgments, Advisory Opinions and Orders, The Corfu Channel Case (Merits), judgment of April 9th, 1949, p. 35.

36 I.C.J. Reports of Judgments, Advisory Opinions and Orders, judgment of June 27th, 1986, see inter alia paragraphs 202, 208, 209, 210 et seq. See also the Order of 10 May 1984, I.C.J. Reports, 1984.

37 Cf. Röling, 1986, op. cit. supra: "The first qualification - that force must be directed 'against the territorial integrity of political independence' of the injured State - refers to Art. 10 of the Covenant of the League of Nations, by which the members undertook to respect and preserve as against extemal aggression the territorial integrity and existing political independence of all Members of the League." (p. 4). 
for a certain kind of organization representing population, the right-holder of the right to peace is the state and not its population as an entity somehow dissociated from it. Although the ultimate purpose of the outlawry of aggression remains, of course, "to save succeeding generations from the scourge of war" 38 , people enjoy this right merely in a derivative way as a reflex right 39 or non-enforceable grant. When the current organizational premises of the world community are taken into account, this construction to secure a (mode of) peaceful co-existence seems quite realistic. 40

\section{The Right of Self-Determination}

The right of self-determination that belongs to the category of peremptory legal norms is the so-called external right of self-determination. As appears from the wordings of the

38 U.N. Charter, Preamble.

39 See for the original and current usage of the term "reflex right" in particular, Vierdag, E. W., The legal nature of the rights granted by the Intemational Covenant on Economic, Social and Cultural Rights, 9 Netherlands Yearbook of International Law (1978), p. 96 et seq.

The U.N. G.A. Declaration on the Preparation of Societies for Life in Peace of 15 December 1978 $(33 / 73)$ does not detract from the conclusion on the derivative nature of the right to peace, it merely serves as a reminder of the preambular phrases of the U.N. Charter that one of the fundamental purposes of the United Nations is to maintain intemational peace and security as is saving succeeding generations from war; it further repeats the various obligations of states to abstain from the use of force, thus reinforcing the derivative character of the right concerned. The same holds for the U.N. G.A. Declaration on the Right of Peoples to Peace of 12 November 1984 (39/11). I would like to add that the attempts by the General Assembly to create an individual or peoples' right to peace seem to be self-defeating to say the least, in virtue of the terminology employed to accomplish this goal: The right to peace is said to be a right of individuals, states, peoples and mankind respectively.

Another problematic aspect of a right to peace, given the current organizational structure of the world in national states, would be its liability to derogations justified by utilitarian arguments to an extent to which the other human rights, with the possible exception of the right of self-determination, are not. Although I will not elaborate this point here, it could be illustrated by asking what happened to the right to peace of the Iraqi people during the Gulf War?

40 Cf. Tomuschat, C., Recht auf Frieden. Ein neues Menschenrecht der dritten Generation?, 40 Europa Archiv, Zeitschrift für Intemationale Politik (1985), p. 271 et seq., who is quite clear about the legal character of the right to peace: "Bei einem Recht auf Frieden hingegen werden individuelle Rechtsansprüche überhaupt undenkbar. Es gibt keinen individuellen Frieden. Frieden ist ein Gesamtzustand, in der Sprache der Nationalökonomie ein 'public good', der sich aus dem Zusammenwirken aller derjenigen Kräfte ergibt, die mächtig genug sind, dem historischen Geschehen ihren Stempel aufzudrücken." "Bei einem Recht auf Frieden lassen sich hingegen keine Sachgesetzlichkeiten erkennen, die dazu nötigen würden, den Staat als das primäre Völkerrechtssubjekt zu übergehen." "... daß mit dem Recht auf Frieden die menschenrechtliche Dimension verlassen ist, weil der Einzelne nicht Träger eines solchen Rechts sein kann, und daß auch die Etikettierung als Recht der Völker ein Recht auf Frieden aus der hergebrachten zwischenstaatlichen Beziehungsebene kaum heraushebt ..." (resp. pp. 273, 274 and 278.) 
Declaration on the Granting of Independence to Colonial Countries and Peoples ${ }^{41}$, this right connotes accession to independent statehood of former colonies. 42

The correlative duty of this right rests with the states which are responsible for (maintaining) colonial domination. These states are under the obligation to end "the subjection of peoples to alien subjugation, domination and exploitation" 43 and to refrain from such behaviour in future. The right of self-determination, in other words, can particularly be understood as freedom from imperialism. 44 The peremptory obligation to refrain from colonial subjection can be considered a basic organizational rule of the modern international system which not only presumes the formal equality of its constituent parts, but simultaneously clearly confirms it.

That the right of a subjected people to external self-determination changes at once into obligations of the newly independent state, both as regards the people it now represents and as regards its fellow states, need not detain us here as such a transition is quite familiar in international law. Compare, for instance, the doctrine of state-responsibility as regards the rights and subsequent obligations of succesful liberation movements towards injured aliens who find themselves in the territory which forms the stage of such internal upheavals. 45

The designation of an external right of self-determination naturally presupposes an internal right of self-determination. The contents of the internal right of self-determination might be elucidated with reference to the classical social contract theories in western philosophy such as developed, inter alia, by John Locke. These theories hold that men renounce some of their powers to enter into a social contract and/or a govemmental contract to form respectively a society and a government. With respect to such a governmental contract it is

41 U.N. G.A. Res. 1514 (XV) of 14 December 1960, "Believing that the process of liberation is irresistable and irreversible and that, in order to avoid serious crises, an end must be put to colonialism ..."; "Solemny proclaims the necessity of bringing to a speedy and unconditional end colonialism in all its forms and manifestations" (Preamble). See also sub 1. This declaration was seen (together with Resolution 1541 which amplified it) as the bible of the anti-colonial religion, according to Luard, E., A History of the United Nations, Volume 2: The Age of Decolonization, $1955-1965$, Houndmills 1989, p. 186; see for the way the declaration came into being, p. 180 et seq.; cf. also art. 16 of the Charter of Economic Rights and Duties of States, U.N. G.A. Res. 3281 (XXIX) of 12. December 1974.

42 Cf. Donnelly, J., Human Rights, Individual Rights and Collective Rights, in Berting 1990, op. cit. supra, "But contemporary political practice restricts the right to self-determination largely to those peoples who have been or are subject to (Westerm) imperial domination." (p. 46). Declaration on the Granting of Independence (see note 41), sub 1.

44 Donnelly, 1990, op. cit. supra, p. 47.

45 Cf. articles 14 and 15 of the I.L.C. Draft Articles on States Responsibility, Texts of the Articles of Part 1 of the Draft adopted by the Commission on First Reading, Report of the International Law Commission on the work of its thirty-second session. Doc. A/35/10, p. 31: see also Brownlie, I., State Responsibility, Part 1, Oxford 1983, p. 178. 
maintained that as long as this governing body exercises these powers correctly, i.e. does not abuse them, men should abide by its rule. As soon, however, as the governors betray the trust given to them by using the entrusted powers for different ends than originally agreed upon, men are entitled to reassume their original powers from the trustees. 46

The gist of contemporary thinking about the internal right of self-determination can be considered a revival of this aspect of the classical contractual notion of government applied to minorities. 47 Compare for instance Rama Rao's remarks as regards the position of the Kashmiris in India. Without passing judgment on the plausibility of his remarks, the argument he uses to reject their claims to self-determination illustrates this point. He argues in effect that the equal political liberties, periodical elections, regional autonomy and other

46 "In some systems, the contract is a once-and-for-all, irrevocable act, understood to have been performed in the remote past ... but in others it appears as a continuing understanding that is perpetually being renewed and is regarded rather as a trust than as a contract (Locke)." Laslett, $P$., Social Contract, in Edwards, P. (ed.), The Encyclopedia of Philosophy, New York (1967) 1972, Vols. 7 and 8, p. 446.

"Unlike Hobbes, Locke was persuaded that men are capable of judging whether they are cruelly subjected and unjustly treated. Since one reason for men entering into the social contract is to avoid a state of war, the contract is broken when the sovereign puts himself into a state of war with the people by becoming a tyrant." Clapp, J. G., Locke, John, in Edwards, op. cit. supra, Vols 3 and 4 , p. 499.

"... whenever the Legislators endeavour to take away, and destroy the Property of the People, or to reduce them to Slavery under Arbitrary Power, they put themselves into a state of War with the People, who are thereupon absolved from any farther Obedience ..."; "Whensoever therefore the Legislative shall transgress this fundamental Rule of Society; and either by Ambition, Fear, Folly or Corruption, endeavour to grasp themselves, or put into the hands of any other an Absolute Power over the Lives, Liberties, and Estates of the People; By this breach of Trust they forfeit the Power, the People had put into their hands, for quite contrary ends, and it devolves to the People, who have a Right to resume their original Liberty, and, by the Establishment of a new Legislative (such as they shall think fit) provide for their own Safety and Security, which is the end for which they are in Society. What I have said here, concerning the Legislative, in general, holds true also conceming the supreme Executor, who having a double trust put in him, both to have a part in the Legislative, and the supreme Execution of the Law, Acts against both, when he goes about to set up his own Arbitrary Will, as the Law of Society. He acts also contrary to his Trust ...". Locke. J. Two Treatises of Govemment, The Second Treatise, edited by Laslett, P., John Locke, Two Treatises of Government, A critical edition with an introduction and apparatus criticus, Cambridge 1970, sec. ed., par. 222.

47 Although the classical contractarian theories referred to assume homogenous societies without ethnical or other minorities, I do not consider this assumption a pertinent obstacle to applying such theories to contemporary societies which are non-homogenous. A theory such as the one expounded by John Locke, for instance, is unacceptable to modern thought with respect to some of its ideas conceming property. Such verdict, however, leaves the many other valuable ideas and in particular the essence of Locke's Treatises intact. 
fundamental rights such as are guaranteed under the federal constitution of India are sufficient grounds to reject the claim to self-determination of the Kashmiri people. 48

The secretary-general of the recently created Unrepresented Nations and Peoples Organization ("U.N.P.O") conveyed a similar line of reasoning when asked in an interview whether the Dutch province Friesland would be eligible for membership of the U.N.P.O. His answer was that Friesland would be so the moment the Frisian people would consider that no justice was done to them within the Netherlands. 49 Lastly, in the words of Umozurike:

"if one of the constituent peoples of a state is denied equal rights and discriminated against, the ... full rights of self-determination will revive." 50

These observations are confirmed indirectly by paragraph 7 of the Declaration on Friendly Relations, since the declaration does not authorise secession or dismemberment of any State which complies with the principle of equal rights and self-determination of peoples and possesses a govemment representing the whole people belonging to the territory without distinction as to race, creed or colour. Self-determination should be understood as internal self-determination in the sense indicated, however, if the provision is not to invalidate itself.

The internal aspect of the right to self-determination is typical of the first generation rights as it explicitly stresses participation of people in society on the basis of formal equality.

48 Quoted by Koteswara Rao, M., Right of Self-determination in the post-colonial era: a survey of juristic opinion and state practice, 28 Indian Journal of International Law (1988), p. 59; cf. inter alia, Sadullah, S., Kashmir - a testing ground for the New World Order, The Daily Jang London, 25 July 1991, on the actual respect for "the other fundamental rights" enjoyed by the Kashmiri people; see also Amnesty International Jaarboek '90 (Yearbook), p. 233.

49 Hegener, M., Volkeren zonder land verenigd in alternatieve VN, NRC Handelsblad, 12 February 1991. In this respect I would like to add that the Covenant of the Unrepresented Nations and Peoples Organization (signed on 11 February 1991) appears to be contradictory as article 5 provides that "Participation [in the U.N.P.O., mz] is open to all Nations and Peoples who are inadequately represented at the United Nations ..." (emphasis added) on the one hand, and on the other hand stipulates in article 25 that the organization shall cease to exist, inter alia, in the event all participants obtain independent representation at the United Nations. The last-mentioned provision clearly indicates that the nation or peoples concerned have attained independent statehood, whereas the former provision does not imply this condition. The phrase "inadequately represented" can equally cease to apply as soon as the government of the state on whose territory the people concerned live and which previously did not represent this people, will represent it.

50 Umozurike, U. O., quoted by Koteswara Rao, op. cit. supra, p. 60 . I take it that the right referred to is the external right of self-determination. 


\section{The Right of Permanent Sovereignty over Natural Resources}

The right to the utilization of the natural wealth and resources of one's country originated as an economic and social aspect of the right of self-determination.51 This origin appears from the way the articles 1 of respectively the Political and Social Covenant are drafted. The respective paragraphs 1 of these articles cover political self-determination and the respective paragraphs 2 economic self-determination: "All peoples may, for their own ends, freely dispose of their natural wealth and resources ...".52 Analogous to the - political right of self-determination which was intended as an instrument to end colonial administration, the right to dispose over local natural resources likewise formed an instrument against exploitation by foreign powers. 53

Paragraph 2 of the Resolution on Permanent Sovereignty over Natural Resources of 197354 is reminiscent of this historical background:

"[The General Assembly] supports resolutely the efforts of the developing countries and of the peoples of the territories under colonial and racial domination and foreign occupation in their struggle to regain effective control over their natural resources."

With the progress of the decolonization process the emphasis on "peoples" as the bearers of the right to control natural resources diminished and the right concemed came to be considered an attribute of "sovereignty" such as is expressed not only in the name but also in the preamble of the resolution referred to above: "reiterating ... that an intrinsic condition of the exercise of the sovereignty of every State is that it be exercised fully and effectively over all its natural resources ...". And in paragraph one of the same resolution:

51 Zakariya, H. S., Sovereignty over natural resources and the search for a new intemational economic order, in Snyder, F. E. / Sathirathai, S. (eds.), Third World Attitudes Toward International Law, An Introduction, Dordrecht 1987, p. 638. Cf. also the preamble of U.N. G.A. Res. 1803 (XVII) of 14 December 1962 on Permanent sovereignty over natural resources.

52 Cf. also art. 25 of the Social Covenant and the identical art. 47 of the Political Covenant.

53 Schrijver, N. J., Permanent Sovereignty over Natural Resources versus the Common Heritage of Mankind: complementary or contradictory principles of intemational economic law?, Series Development \& Security, Rijksuniversiteit Groningen, no. 21, 1987; "There can be almost no doubt as to the motives to formulate the principle of PSNR [Permanent Sovereignty over Natural Resources, mz] and on the objectives pursued by it. The principle was developed in the 1950s in an effort, on the one hand, to secure for peoples living under colonial rule the future benefits arising from exploiting natural resources in their territories and, on the other, to provide newly-independent States with a shield against disproportionate infringement of their sovereignty by rights or claims of other States and foreign companies." (p. 5).

54 U.N. G.A. Res. 3171 (XXVII) of 17 December 1973. 
"[The General Assembly] strongly reaffirms the inalienable rights of States to permanent sovereignty over all their natural resources, on land within their international boundaries, as well as those in the sea-bed, in the subsoil thereof, within their national jurisdiction and in the superjacent waters." 55

The corresponding obligation of this right rests with the other states which currently make up the state community. They are under the obligation to refrain from interference with the discretion enjoyed by independent states in the management of their natural resources, or to put it more bluntly, they are obliged to refrain from economic imperialism. 56

\section{The Right to Benefit from the Common Heritage of Mankind}

In the previous paragraphs three third generation rights were analyzed. These rights strive, like the first generation rights, to secure formal equality 57 and participation on the basis of formal equality, albeit of states in the international community. 58 As a parallel, however, to the second generation of human rights, I would like to introduce a fourth generation. This

55 Cf. also art. 2 par. 1 of the Charter of Economic Rights and Duties of States, U.N. G.A. Res. 3281 (XXIX) of 12 December 1974: "Every State has and shall freely exercise full permanent sovereignty, including possession, use and disposal, over all its wealth, natural resources and economic activities".

56 Cf. Donnelly 1990, op. cit. supra; "Likewise, the right of a people to its natural wealth and resources can be seen as a guarantee that the material means to satisfy a wide range of rights will not be subject to a continued plunder by foreign states or corporations." (p. 46).

It would be possible to argue for a so-called internal right to natural resources along lines similar to those expounded in the previous paragraph with respect to the intemal right of self-determination. Although I will not elaborate this point, an illustration would be the Australian govemment's decision not to exploit the riches of Coronation Hill in accordance with the wishes of the Jawoyn aborigines residing there. Cf. Kregten, $H$. van, Bula mag vredig doorslapen, wereld blijft ramp bespaard, NRC Handelsblad, 19 June 1991. This intemal aspect of the right concemed shares the participatory characteristic of the rights of the first generation.

57 Cf. Rawls, 1972, op. cit. supra: "The basic principle of the law of nations is a principle of equality. ... This principle is analogous to the equal rights of citizens in a constitutional regime." (p. 378).

58 Such participation is demanded on the basis of independent statehood as one of its attributes. See for this participatory aspect, for instance, the Declaration on Principles of Intemational Law conceming Friendly Relations and Co-operation among States in accordance with the Charter of the United Nations, U.N. G.A. Res. 2626 (XXV) of 24 October 1970 on the principle of sovereign equality of States ("they have equal rights and duties and are equal members of the intemational community") and art. 10 of the Charter of Economic Rights and Duties of States, U.N. G.A. Res. 3281 (XXIX) of 12 December 1974: "All States are juridically equal and, as equal members of the intemational community, have the right to participate fully and effectively in the intemational decision-making process in the solution of world economic, financial and monetary problems, inter alia, through the appropriate intemational organizations in accordance with their existing and evolving rules, and to share equitably in the benefits resulting therefrom". (emphasis added.) 
fourth generation would consist of the right to benefit from the common heritage of mankind and possibly of the right to development and the right to food as well.

The second generation is characterized by a drive to change existing national structures by codification of claims which are to result in societies which are characterized by equal opportunities and a minimum level of well-being for all by means of securing changes in pattems of distribution. The fourth generation shares this characteristic of the second one: substantive or material equality which has to be accomplished by means of (re)distribution. The distinguishing characteristic is of course the level at which the claims of the respective generations operate: The second generation of human rights operates at the national level and the fourth one at the international level.59

There is, however, another distinguishing characteristic. In the case of the second generation rights, the premise of all action is the state as the vehicle of social change. In case of the fourth generation, however, the state is treated as a fiction, a construction which is useful (or unavoidable) for now, but which will perhaps be outdated tomorrow. The cause of this, to a certain extent, diminished role of the state is the explicit mention of mankind at the receiving end of fourth generation rights. The fact that mankind is only imperfectly organized, or rather represented, by states is accidental in the sense that this form of organization is not inherent in the right concerned.

These remarks will be clarified by an analysis of the fourth generation right to benefit from the common heritage of mankind.

\section{Part Two}

\section{The Common Heritage of Mankind}

The expression "common heritage of mankind" at first sight conjures up images of valuables which are considered as having intrinsic value and which should therefore be administered and preserved altruistically with an eye to eternity for the benefit of future generations. The qualification of things - material and immaterial - as belonging to the common heritage of mankind with this particular meaning does figure in international law.

59 Please, refer to the Annex for a diagram of the various generations of human rights. 
An example at the universal level is the 1972 UNESCO Convention for the Protection of the World Cultural and Natural Heritage.60

At the regional lvel there are various treaties which refer to "a common heritage". This comes as no surprise since these regional treaties are drafted and entered into by a regional group of states which are united by a common heritage they are determined to maintain and preserve. The states united in the Council of Europe, for instance, take the spiritual and moral values of their peoples as the relevant common heritage which they pledged themselves to maintain.61 The states parties to the European Convention for the Protection of Human Rights and Fundamental Freedoms 62 refer in the Preamble to their likemindedness and their common heritage of political traditions, ideals, freedom and the rule of law. 63

There is, however, another meaning of the term "common heritage of mankind" than this mainly preservative one. The same concept features in international law with an entirely different and quite opposite meaning to preservation. The common heritage then serves to underline tangible benefits to be distributed. This concept of common heritage of mankind with the connotation of distribution is used to designate certain territories situated outside the limits of national jurisdiction. The history of international law teaches that such invocation takes place as soon as these territories are deemed to possess something valuable from an economic point of view, such as, nonrenewable, natural resources and - as a supervening factor - when modern technology promises the possibility of actual exploitation of the valuables.

Outer space, or rather, the moon and other celestial bodies in space, are an example of such attractive territory. Another example is a part of the High Seas, in terms of the 1982 United Nations Convention on the Law of the Sea64, better known as "the Area".

60 Adopted on 16 November 1972. Entry into force on 17 December 1975. I.L.M., vol. XI, 1972, p. 1358. Cf. Goy, R. H. M., The Intemational Protection of the Cultural and Natural Heritage, 4 Netherlands Yearbook of Intemational Law (1973), p. 117 et seq.

61 Preamble, Statute of the Council of Europe. Adopted on 5 May 1949. Entry into force on 3 August 1949. U.N. Treaty Series, vol. 87, p. 103, see for the text: European Treaty Series, no. 1.

62 Adopted on 4 November 1950. Entry into force on 3 September 1953. European Treaty Series, no. 5.

63 Cf. also the European Cultural Convention of 19 December 1954, which entered into force on 5 May 1955, European Treaty Series, no. 18 and the Convention for the Protection of the Architectural Heritage of Europe of 3 October 1985, which entered into force on 1 December 1987, European Treaty Series, no. 121.

64 Adopted on 10 December 1982 by the Third United Nations Conference on the Law of the Sea. Opened for signature on 10 December 1982 (A/CONF. 62/122 and Corr. 1 to 11). Not yet in force. 
Both heritages are situated in remote and, I assume, desert areas. Both areas are threatened by the practice of who comes first, first served. To avoid such a practice, the status of common heritage is bestowed upon such areas.

\section{The Introduction of the Concept of the Common Heritage of Mankind in International Law}

Although "mankind" as a beneficiary of outer space activities is said to be mentioned as early as 1954 by Mr. Aldo Cocca at a conference of the International Astronautical Federation65, the actual introduction of the concept of the common heritage of mankind in international law66 is due to Mr. Arvic Pardo. Ambassador Pardo, representing Malta at the United Nations, dramatically67 expressed his fears to the General Assembly that the oceanfloor, its subsoil and its resources would be subjected to exploration, occupation and exploitation by national states. If no restrictive measures would be taken, he feared that these resources would be exploited and possibly depleted by the technologically most advanced states of the world. To avoid such exploitation and depletion he suggested to declare the said area and its resources to be the common heritage of mankind and to operationalize this concept in a convention. 68

In other words, Pardo wanted to curb the age-old res communis character of the high seas of which the chief characteristic is (almost) unrestricted allowance of use and exploita-

65 Williams, S. M., The role of equity in the law of outer space, 1 International Relations (1975), p. 797; Williams, S. M., Intemational Law before and after the Moon Agreement, 7 Intemational Relations (1981), p. 1176; Cocca, A. A., Common Heritage of Mankind: A Basic Principle of the Intemational Legal System, Proceedings of the thirty-first colloquium on the law of outer space, International Institute of Space Law of the Intemational Astronautical Federation, October 8-15, 1988, Bangalore, India. Published by the American Institute of Aeronautics and Astronautics, Washington 1988, pp. 89, 90.

66 That is, with reference to distribution in contradistinction to preservation, cf. par. 8.

67 Cf. "The dark oceans were the womb of life: from the protecting oceans life emerged. We still bear in our bodies - in our blood, in the salty bittemess of our tears - the marks of this remote past. Retracting the past, man, the present dominator of the emerged earth, is now retuming to the ocean depths. His penetration of the deep could mark the beginning of the end for man, and indeed for life as we know it on this earth: it could also be a unique opportunity to lay solid foundations for a peaceful and increasingly prosperous future for all peoples." U.N. G.A., 22nd session, Official Records, First Committee, 1515th Meeting, 1 November 1967 (A/C.1/PV.1515), p. 2.

68 Pardo, A., U.N. G.A., 22nd session, Official Records, First Committee, 1516th Meeting, 1 November 1967 (A/C. 1/PV.1516), p. 2; see in particular the principles with the numbers $10 \mathrm{c}$ ), d) and 13 mentioned by Pardo. 
tion. ${ }^{69}$ Pardo's suggestions resulted in the Declaration of Principles Governing the Sea-Bed and the Ocean Floor, and the Subsoil Thereof, beyond the Limits of National Jurisdiction.70 This declaration, subsequently known as the "Common Heritage Declaration", contained in embryonic form the regime which is now to govern that part of the high seas which is called "the Area" (the sea-bed and ocean floor and the subsoil thereof, beyond the limits of national jurisdiction) such as is codified in the United Nations Convention on the Law of the Sea of 1982. The Area and its resources are proclaimed to be the common heritage of mankind in art. 136 of this Convention. 71

Before the Convention on the Law of the Sea was adopted, however, the concept of the common heritage of mankind was introduced into another treaty, the Agreement on Activities of States on the Moon and other Celestial Bodies of 1979, at the initiative of Argentine Mr. Cocca. Article 11 paragraph 1 of this Agreement reads:

"The moon and its natural resources are the common heritage of mankind ..."72

69 Cf. art. 2 of the Convention on the High Seas of 29 April 1958. Entry into force on 30 September 1962, U.N. Treaty Series, vol. 450, p. 11 et seq.; cf. for the restrictions referred to, inter alia, articles $19,24,26$ and 27.

70 U.N. G.A. Res. 2749 (XXV) of 17 December 1970; cf. also the 1974 Charter of Economic Rights and Duties of States, Chapter III (Common Responsibilities towards the International Community), art. 29.

71 Cf. also art. 140 and art. 311 par. 6.

72 Before the Moon Treaty was adopted, however, yet another treaty was signed: the Treaty on Principles Governing the Activities of States in the Exploration and Use of OuterSpace, including the Moon and other Celestial Bodies of 1967. Opened for signature on 27 January 1967. Entry into force on 10 October 1967, U.N. Treaty Series, vol. 610, p. 206 et seq., hereinafter cited as the Outer Space Treaty. In this treaty "the province of all mankind" was introduced, as follows, in article 1: "The exploration and use of outer space, including the Moon and other celestial bodies, shall be carried out for the benefit and the interests of all countries, irrespective of their degree of economic and social development, and shall be the province of all mankind".

The legal regime established by this treaty for outer space is akin to that of the High Seas (that is, excluding "the Area"): res communis. Cf. Cassese, A., International Law in a Divided World, Oxford 1986 II, p. 388; Wassenbergh, H. A., Speculations on the law goveming space resources, 5 Annals of Air and Space Law (1980), pp. 616,621, 623; Goedhuis, D., The present state of international relations in outer space, 7 International Relations (1983), p. 2286; Williams, 1981, op. cit. supra, pp. 1168, 1169; Brownlie, I., Principles of Public International Law, Oxford 1990 (4th ed.), p. 267; Röling, B.V A., Volkenrecht en Vrede, Deventer 1985 (3rd rev. ed.), p. 126.

The Moon Treaty can be considered as lex specialis in relation to the Outer Space Treaty with the result that some parts of the res communis outer space, i.e., the moon and other celestial bodies (excluding the planet earth) fall under the more restrictive regime of res communis humanitatis or common heritage ov mankind. Cf. Wassenbergh, 1980, op. cit. supra, p. 624. 
Both the Convention on the Law of the Sea and the Moon Treaty provide that benefits deriving from these common heritages are to be shared equitably. 73 Whereas the idea of equitable sharing of profits is considered to be "the real linchpin"74 of the concept of the common heritage of mankind, I would consider the subject which is to benefit from this sharing its keyman. The question of mankind as a possible subject of international law has given rise to heated debates about the status of "mankind". Some consider mankind as an actual subject of international law 75 while others consider "mankind" as a concealment, yet a beautiful one, of unsolved legal problems. ${ }^{76}$ The present writer is of the opinion that whether or not "mankind" is a subject of international law, the term is at least resourceful. Its resourcefulness stems from the treaty-based context of distribution in which it is introduced and which allows it to generate definite obligations for the community of states. Although sceptics might argue that there is no difference between "individuals" or "peoples" as rightholders of a right to peace and "mankind" as beneficiary of common heritages, there is in fact a difference. The concept of the common heritage of mankind does not entail the pretensions of a subjective right which could be enforced by individuals but "merely" imposes certain obligations towards mankind on states to be implemented by those states. In addition, the fact that "mankind" did find a place in treaties, thereby explicitly giving rise to obligations for the states parties thereto, equally sets it apart from the so far abortive attempts 77 to create a subjective right to peace.

Nevertheless, two questions should be answered with respect to "mankind". Is it sensible to deny "mankind" meaning and potential power now that it found its way as the inheritor of two distinct heritages in conventions of which one has actually entered into force? And how far does mankind extend in time; that is, how many generations does mankind comprise in this connection? The answer to the last question I defer to par. XI.

As regards the first question, the codification of "mankind" at the receiving end of tangible benefits forms a clear indication or even acknowledgment that the current organization of the world in states is somehow unsatisfactory. If one considers that more people will be

73 In this article I will confine myself to the common heritage which is situated in outer space, with reference to the relevant articles in the Moon Treaty, cf. art. 11 of the Moon Treaty and Christol, $C$. $Q$., The Moon Treaty Enters into Force, 79 American Journal of International Law (1985), pp. $164,165$.

74 Cassese, 1986 II, op. cit. supra, p. 391.

75 Cf. Cocca, 1988, op. cit. supra, pp. 89, 91; Fasan, E., The meaning of the term "mankind" in space legal language, 2 Joumal of Space Law (1974), p. 125 et seq.; his main conclusion is that no denial of the actual process of mankind becoming a new legal subject of international law is possible.

76 Bueckling, A., The strategy of Semantics and the "Mankind Provisions" of the Space Treaty, 7 Journal of Space Law (1979), p. 22.

77 Cf. note 39. 
represented - potentially, as yet - in the U.N.P.O. than currently in the U.N., this dissatisfaction is not difficult to understand.78

However, the primary actors in the world are still states. As long as they remain so, meanwhile the fiction of mankind as legally represented by states 79 will have to do, subject to the following qualification. As mankind is the actual bearer of the right to benefit from the common heritage of mankind, the states which currently act as mankind's trustees will have to act accordingly.

\section{Background}

As long as the state is the primary actor in international affairs and law, newly independent states will struggle to obtain the same rights as the vested ones. Such struggle will result in the demand for formal equality and the concomitant right to participate on that footing in the world community. 80

This formal equality cannot be fully realized, however, as long as the body of international law remains unaltered and unattuned to the problem of the disparities in wealth, military and economic power in the world. Such formal equality will result in de facto discrimination if this problem is not tackled. 81

78 Even if one ignores these facts, "mankind" should not be denied legal significance since it plays a role in two treaties. Cf. art. 31 of the Vienna Convention on the Law of Treaties of 23 May 1969 (opened for signature on 23 May 1969; entry into force on 27 January 1980; U.N. Treaty Series, vol. 1155 , p. 331 et seq.): "A Treaty shall be interpreted in good faith in accordance with the ordinary meaning to be given to the terms of the treaty in their context and in the light of its object and purpose".

79 I therefore disagree with the opinion of Nagy, who maintains that mankind is more than the aggregate of states with their respective populations in so far as he bases this opinion on the argument that a totality is more than the sum of its parts and the observation that some states do not represent their peoples. This observation does not impair the logics of the argument that the current division of the world in states equals mankind. In so far as Nagy basis his opinion on the argument on future generations, I tend to agree with him; cf. par. 12. Nagy, B., Common Heritage of Mankind: The Status of Future Generations, Proceedings of the thirty-first colloquium on the law of outer space, Intemational Institute of Space Law of the Intemational Astronautical Federation, October 8-15, 1988, Bangalore, India. Published by the American Institute of Aeronautics and Astronautics, Washington, 1988, p. 321.

80 Röling, B. V.A., Intemational Law in an Expanded World, Amsterdam 1960, p. 77; cf. also: "This Afro-Asian nationalism and this idolization of sovereignty are not merely reactions to the period of dependence. They are the means of clearing away the last traces of bondage and of preventing any further bondange - that is their extemal function ..." (p. 78).

81 Johnston refers to the confusion between the principles of equal protection of the law or equality before the law and that of equal capacity for rights and obligations. The first, he argues, is a 
The nonaligned states and the so-called group of seventy-seven less developed nations realized clearly in the late sixties and early seventies, that such formal equality "had not paid off"82. "Having a new flag, a new anthem, a seat in the U.N. and a national airline had not worked a fundamental reorderingof the colonialist order." 83 Perceptions as these led to the adoption of the General Assembly Declaration on the Establishment of a New International Economic Order in 1974, "which shall correct inequalities and redress existing injustices, make it possible to eliminate the widening gap between the developed and the developing countries"84, and of a Programme of Action on the Establishment of a New International Economic Order. 85

The main body of international law came into being in a period when its creators were limited to a handful of states situated in the western hemisphere. 86 Naturally, the law which came thus into being reflected and still reflects the interests of these states 87 thereby living up in truly Orwellian fashion to the adage "all states are equal, but some states are more

procedural principle and the second one is a substantive norm related to the concept of distributive justice, both of which are logically unconnected. They don't seem to be so, however, in practice. Reference only need to be made of the disruptive and discriminatory affects neglicence of the second principle could have on the first (cf. note 79). Johnston, D. M., The Foundations of Justice in International Law, in Macdonald, R. St. J. / Johnston, D. M. / Morris, G. L. (eds.), The International Law and Policy of Human Welfare, Alphen aan den Rijn 1978, pp. 121, 122. Cf. Jennings, $R$. Y., General Course on Principles of Intemational Law, Ch. 4: The High Seas, Airspace and Outer Space, Recueil de Cours, 1967 II, Leiden 1969, p. 412: "the provision for free access for all [the reference is to art. 1 of the Outer Space Treaty, mz] is reminiscent of the English judge's statement that the law is, like the Ritz Hotel, open to all on a basis of strict equality".

82 Ferguson, C. C., Redressing Global Injustices: The Role of Law, in Snyder / Sathirathai, 1987, op. cit. supra, p. 369; cf. the Charter of Algiers, Adopted at the Ministerial Meeting of the Group of 77 on 24 October 1967, Proceedings of the United Nations Conference on Trade and Development, Second Session, Vol. I and Corr. 1 and 3 and Add. 1 and 2, Report and Annexes, p. 431 et seq.

83 Ferguson, 1987, op. cit. supra, p. 369; cf. also: "Hence in Algiers in 1973, a conscious decision was taken [by the nonaligned group of states and the group of seventy-seven, $\mathrm{mz}$ ] that the real issues in the world were economic and that the issues are equity (a fair share of what's in the world) and justice (participation in the decisions that affect those countries so newly emerged)." (p. 369).

84 Preamble, U.N. G.A. Res. 3201 (S-VI) of 1 May 1974.

85 U.N. G.A. Res. 3202 (S-VI) of 1 May 1974; cf. also Berting's characterization of the second generation rights, quoted in par. 2 .

86 Sarin, M. L., The Asian-African States and the Development of International Law, in Dupuy, R. J. (ed.), The Future of International Law in a Multicultural World, Workshop, The Hague, 17-19 November 1983, The Hague, 1984, p. 137 et seq.; Flory, M., Adapting Intemational Law to the Development of the Third World, in Snyder / Sathirathai, 1987, op. cit. supra, p. 803; Ferguson, 1987, op. cit. supra, pp. 372, 373.

87 Anand, R. P., Attitude of the Asian-African States Toward Certain Problems of Intemational Law, in Snyder / Sathirathai, 1987, op. cit. supra, pp. 5, 6, 10; Prakash Sinha, S., Perspective of the Newly Independent States on the Binding Quality of Intemational Law, in Snyder / Sathirathai, 1987, op. cit. supra, p. 23; Sarin, 1984, op. cit. supra, p. 126. 
equal than others". This fact is one of the reasons, or even the main reason, that the "new" states are not inclined to accept the application of many of its rules 88 and want some of them changed.89

The states which in the past created the body of international law, however, today form only a minority in the expanded state community. The claims made by the new states in terms of such concepts as the common heritage of mankind are nothing but a demand for an international law which is tailored to the needs and interests of the modern - expanded world community. 90

88 And are equally unwilling to accept the compulsory jurisdiction of an international court, in particular of the Intemational Court of Justice. Cf. Röling, 1960, op. cit. supra, p. 76 and in the same vein, Röling, 1985, op. cit. supra, p. 205 et seq. and Sarin, 1984, op. cit. supra, pp. 125, 126.

89 Cf. Schrijver, N., Revisiting the Dutch Initiative for a Development Charter, in Baehr, P. R. I Castermans-Holleman, M. C. (eds.), The Netherlands and the United Nations, Selected Issues, The Hague, 1990, who refers in this connection to the wish of the developing countries "to change the rules of the game" at p. 10.

90 Cf. Judge Ammoun in his seperate opinion in the Barcelona Traction Case, Barcelona Traction, Light and Power Company, Limited (New Application: 1962), Judgment of 5 February 1970, I.C.J. Reports, 1970: "Among the treaties which have been in question, it is necessary to go back to those which organized intemational society in the eighteenth and nineteenth centuries, and at the beginning of the twentieth century. It is well known that they were concluded at the instigation of certain great Powers which were considered by the law of the time to be sufficiently representative of the community of nations, or of its collective interests. Moreover, the same was the case in customary law: certain customs of wide scope became incorporated into positive law when in fact they were the work of five or six Powers." (p. 308). "It thus becomes easier to understand the fears of a broad range of new States in three continents, who dispute the legitimacy of certain rules of international law, not only because they were adopted without them, but also because they do not seem to them to correspond to their legitimate interests, to their essential needs on emerging from the colonialist epoch, nor, finally, to that ideal of justice and equity to which the international community, to which they have at last been admitted, aspires. What the Third World wishes to substitute for certain legal norms now in force are other norms profoundly imbued with the sense of natural justice, morality and humane ideals." (p. 310). 


\section{The Moon Treaty}

The provision of the Moon Treaty91 in which the moon and its natural resources are declared to be the common heritage of mankind is elaborated principally in paragraphs 5 and 7 of article 11:

"5. States Parties to this Agreement hereby undertake to establish an international régime, including appropriate procedures, to govern the exploitation of the natural resources of the moon as such exploitation is about to become feasible....

7. The main purposes of the international régime to be established shall include:

(a) The orderly and safe development of the natural resources of the moon;

(b) The rational management of these resources;

(c) The expansion of opportunities in the use of these resources;

(d) An equitable sharing by all States Parties in the benefits derived from those resources, whereby the interests and needs of the developing countries, as well as the efforts of those countries which have contributed either directly or indirectly to the exploration of the moon, shall be given special consideration."

The Agreement seemingly limits the scope of the concept of the common heritage of mankind to the moon and its natural resources, but article 1 paragraph 1 provides that "The provisions of this Agreement relating to the moon shall also apply to other celestial bodies within the solar system, other than the earth, except in so far as specific legal norms enter into force with respect to any of these celestial bodies", and thus extends the scope of the said principle. This extension is affirmed by an understanding of article 11 paragraph 1 which is formulated by the Committee on the Peaceful Uses of Outer Space which eliminates all doubts as regards the scope of the concept of common heritage: "The Committee agreed that by virtue of article I, paragraph 1, the principle contained in article XI, paragraph 1, would also apply to celestial bodies in the solar system other than the earth, and to its natural resources." 92

91 Except for the provisions of the Outer Space Treaty which may have some influence as lex generalis in relation to the Moon Treaty on the eventual regime which is to govem the exploitation and use of the natural resources of the moon, mention should be made of U.N. G.A. Res. 1721 (XVI) (A) of 20 December 1961 (International Co-operation in the peaceful uses of outer space) and Res. 1802 (XVII) of 14 December 1962 (Intemational Co-operation in the peaceful uses of outer space) and Res. 1962 (XVIII) of 13 December 1963 (Declaration of Legal Principles Governing the Activities of States in the Exploration and Use of Outer Space). In these declarations, intemational law and in particular the Charter of the United Nations are declared to apply to both outer space and celestial bodies and to the activities of states in outer space or, in other words, the scope of intemational law is extended so as to apply not only to T. but to E.T. as well.

92 U.N. G.A. Official Records: Thirty-Fourth Session, Supplement No. 20 (A/34/20), Report of the Committee on the Peaceful Uses of Outer Space, p. 11. 
Article 11 paragraph 5 provides, in addition to the provisions quoted above, that the establishment of an international régime shall be implemented in accordance with article 18. Article 18 sets a twofold time limit on the establishment of such a régime in addition to the feasibility condition which is formulated in article 11 paragraph 5 . A conference will be convened by the Secretary-General of the United Nations at the request of the states parties to the Moon Treaty at any time after the Agreement has been in force for five years, at which conference, inter alia, the implementation of the provisions of article 11 paragraph 5 will be considered. Although the Moon Treaty is already in force for more than five years, no such conference has been convened as yet. The second limit set by article 18 is the stipulation that the Moon Treaty, the question of its review and the consideration of the implementation of the provisions on the establishment of an international régime, shall be included in the provisional agenda of the General Assembly ten years after the entry into force of the Agreement. The item of the review of the Moon Treaty is not yet introduced to the General Assembly, but should be so in the 1994 session.

The fact that an international régime is not yet established occasioned the question whether a moratorium rests on the exploitation of the moon and its resources until the time when such a régime comes into force. Although scholars are virtually unanimous in their denial that a moratorium exists 93 , it is questionable whether exploitation in the absence of a régime would imply a right to freely enjoy and appropriate the benefits deriving from exploitation, since the states parties to the Moon Treaty are under the obligation to establish a régime as soon as exploitation of the lunar resources is feasible. 94

93 Williams, 1981, op. cit. supra, p. 1187; Williams, S. M., International Law and the Exploitation of Outer Space: A New Market for Private Enterprise?, 7 Intemational Relations (1983), pp. 2478, 2479; Goedhuis, D., Conflicts in the Interpretation of the Leading Principles of the Moon Treaty of 5 December 1979, 28 Netherlands International Law Review (1981), pp. 19, 21, 26; Goedhuis, 1983 , op. cit. supra, p. 2287; Goedhuis, D., Reflections on some of the main problems arising in the future development of space law, 36 Netherlands International Law Review (1989), p. 257; Christol, C. Q., The Common Heritage of Mankind Provision in the 1979 Agreement Governing the Activities of States on the Moon and Other Celestial Bodies, 14 The International Lawyer (1980), pp. 476, 481; Christol, C. Q., The Modem Intemational Law of Outer Space, New York 1982, p. 318; Wolfrum, R., Der Mondvertrag von 1979 - Weiterentwicklung des Weltraumrechts, 21 Europa Archiv, Zeitschrift für Intemationale Politik (1980), p. 667; Danilenko, G. M., The Concept of the "Common Heritage of Mankind" in Intemational Law, 13 Annals of Air and Space Law (1988), p. 259; Gorove, S., Utilization of the Natural Resources of the Space Environment in the light of the Concept of the Common Heritage of Mankind, in Dupuy, 1983, op. cit. supra, p. 108; Larschan, B. / Brennan, B. C., The Common Heritage of Mankind Principle in International Law, 21 Columbia Joumal of Transnational Law (1982), p. 330; Wassenbergh, 1980, op. cit. supra, p. 623; Cassese, 1986 II, op. cit. supra, p. 390.

94 Cf. also art. 11 par. 6 of the Moon Treaty: "In order to facilitate the establishment of the international régime referred to ... States Parties shall inform the Secretary-General of the United Nations as well as the public and the intemational scientivic community, to the greatest extent feasible and practicable, of any natural resources they may discover on the moon". 


\section{Distributive Justice in Outer Space ${ }^{95}$}

Although the Moon Treaty contains the basic principles which are to govern the (future) exploitation of the moon and its natural resources, a communis opinio exists as regards the phrase "equitable sharing" to the effect that it would lack definite meaning.96 This would entail, if true, the impossibility of any practical implementation. In its ultimate sense,

Although I fully subscribe the train of Mr. Narayana Rao's arguments leading to the conclusion that "the presence or absence of a moratorium clause in the agreement [the Moon Treaty, mz] is irrelevant in view of the fact that the moon and its resources are already vested in mankind", not all problems are solved by this observation. In particular not in view of the fact that Narayana Rao's argument proceeds inplicitly from the premise that no vacuum exists between (scientific) exploration and processing and - subsequent - discovery of any resources which would evidence that exploitation is about to become feasible. Narayana Rao, $K$., Common Heritage of Mankind and the Moon Treaty (editorial comment), 21 Indian Joumal of Intemational Law (1981), p. 278. Cf. ant. 6 of the Moon Treary, in particular paragraph 2: "In carrying out scientific investigations and in furtherance of the provisions of this Agreement, the States Parties shall have the right to collect on and remove from the moon samples of its mineral and other substances. Such samples shall remain at the disposal of those States Parties which caused them to be collected and may be used by them for scientific purposes. States Parties shall have regard to the desirability of making a portion of such samples available to other interested States Parties and the international scientific community for scientific investigation...." I will not elaborate this point, but it would seem that the moon and its natural resources are res communis (cf. art. 4 par. 1) until exploitation of the moon and its natural resources is feasible. The moment exploitation is feasible is equally the moment the res communis character of the moon changes into the more restricted regime of res communis humanitatis or common heritage of mankind. This interpretation seems to be confirmed by article 11 par. 8.

95 I would like to thank dr H. J. R. Kaptein for his generous help and constructive criticism on earlier versions of this paragraph.

96 "The same article 11, in paragraph 7(d) establishes an obligation of equitable sharing of the benefits derived from the moon's resources. But there is no definition whatsoever regarding the meaning of this expression."; Williams, 1981, op. cit. supra, p. 1179; "At the same time that attempts are made to understand this relationship [of the common heritage of mankind principle to the res communis principle, $\mathrm{mz}$ ] it will also be necessary to arrange for the identification and implementation of the legal rules which will govem the distribution of the benefits resulting from the application of the CHM [common heritage of mankind principle, $\mathrm{mz}$ ] to future exploitations."; "Although the proposed Law of the Sea Convention facilitates the equitable sharing of financial and other economic benefits, the terms of the agreement do not contain exact criteria specifying how such sharing is to take place. The same is true of the Moon Treaty."; "The command in the Moon Treaty that there shall be an equitable sharing in benefits derived from resources constitutes only a general directive." Christol, 1982, op. cit. supra, pp. 332, 390; see also Vicas, A. G., The New Intemational Economic Order and the emerging space regime, Space Activities and Implications: Where From and Where To at the Threshold of the 80's, Proceedings of the Symposium held on October 16-17, 1980, McGill University, 1981, p. 295; Gorove, S., Studies in Space Law: Its Challenges and Prospects, Leiden 1977, pp. 60, 61; Gorove, 1983, op. cit. supra, pp. 108, 114; Larschan / Brennan, 1982, op. cit. supra, p. 330. 
however, the common heritage of mankind principle is said to strive to global faimess. ${ }^{97}$ To what kind of obligations such faimess would amount to, albeit limited to the extraterrestrial realms, is the object of the present paragraph.

Notions like "faimess", "justice" and related notions such as "equitable sharing" are not very specific by themselves. Different interpretations may lead to different principles prescribing equitable sharing. Therefore it is of some importance to arrive at a specific interpretation of the notion of equitable sharing and the role of, respectively the priority to be assigned to, "interests and needs" and "efforts" as noted in article 11 paragraph 7, sub (d) of the Moon Treaty. Without a plausible specific interpretation, a generally acceptable practical implementation of the treaty concerned is not possible. A general conception of justice and faimess is thus needed in order to arrive at a more specific or definite meaning of the provisions of the Moon Treaty. As noted before, Rawls' theory of justice or justice as fairness is a plausible expression and elaboration of notions of justice and faimess. The theory of justice as faimess brings to light fundamental principles of justice underlying generally accepted notions of the modern state, the rule of law, human rights and related notions. As will be shown below, the methodology applied by Rawls in order to arrive at principles of justice and their practical applications leads to important results in the interpretation of the principles of the Moon Treaty as well.98

Some introductory remarks are needed to sketch Rawls' theory. Justice as fairness is a generalized and abstract version of the classical theories of social contract 99 , combined with the idea of the fundamental value of the individual and of mankind. Rawls uses the device of an "original position" as a counterfactual hypothesis to arrive at principles of justice. "The idea of the original position is to set up a fair procedure, so that any principles agreed to will be just." 100 Some further explanation of the idea of the original position is in order here.

Those who engage in social cooperation are imagined to choose together in one joint act, in an "original position", unanimously "the principles which are to assign basic rights and

97 Christol, 1980, op. cit. supra, pp. 453, 454; Christol, 1982, op. cit. supra, p. 288.

98 In this paper the interpretation of the concept of the common heritage of mankind is limited to the one formulated and applied in outer space, in particular in the Moon Treaty. This means, inter alia, that the analysis does not proceed from a general concept of the common heritage of mankind to a more specific application of it in outer space. See for an argument that proceeds along lines of generality to specifity as regards the concept of the common heritage of mankind, Wolfrum, $R$., Die Intemationalisierung staatsfreier Räume, Die Entwicklung einer internationalen Verwaltung für Antarktis, Weltraum, Hohe See und Meeresboden, Berlin 1984.

99 Rawls, 1972, op. cit. supra, p. 11; cf. the introductory paragraph of this paper. Although these theories of social contract referto national societies, transposal of such theories to the intemational community matches the practice of states to order the intemational society by means of treaties.

100 Rawls, 1972, op. cit. supra, p. 136. 
duties and to determine the division of social benefits" 101 . Although the concept of the "original position" seemingly implies a concrete kind of meeting, it is an imaginary one; the idea is that everyone could in his own mind enter the original position at any time and "simulate the deliberations of this hypothetical situation".102 The original position is characterized by special conditions which are to ensure a fair and rational decision-making process. 103 As regards these conditions Rawls remarks that "The idea here is simply to make vivid to ourselves the restrictions that it seems reasonable to impose on arguments for principles of justice, and therefore on these principles themselves."104

The most important of these restrictions is the so-called veil of ignorance. Persons in the original position are imagined to reach their conclusions without knowing their personal qualities, social position, income, wealth and the like. In virtue of this veil, "the effects of specific contingencies which put men at odds and tempt them to exploit social and natural circumstances to their own advantage" are nullified.105 Thus the original position is an expression of equality. A person in the original position "does not know who he is" and thus he will opt for principles of justice leading to a social order that is acceptable to everybody, whatever his or her personal qualities, social position, income, wealth and so on. More specifically, the methodology of the original position leads to principles of justice protecting the interests of the less well-endowed in society. The basic principles for society which Rawls deduces from the original position are the following:

1. Each person is to have an equal right to the most extensive basic liberty compatible with a similar liberty for others;

2. Social and economic inequalities are to be arranged so that they are both (a) to the greatest benefit of the least advantaged and (b) attached to offices and positions open to all under conditions of fair equality of opportunity.

These principles are the expression of the general conception that "All social primary goods - liberty and opportunity, income and wealth, and the bases of self-respect - are to be distributed equally unless an unequal distribution of any or all of these goods is to the advantage of the least favored". 106

101 Rawls, 1972, op. cit. supra, p. 11 and p. 141.

102 Rawls, 1972, op. cit. supra, p. 138.

103 "To say that a certain conception of justice would be chosen in the original position is equivalent to saying that rational deliberation satisfying certain conditions and restrictions would reach a certain conclusion." Rawls, 1972, op. cit. supra, p. 138.

104 Rawls, 1972, op. cit. supra, p. 18.

105 Rawls, 1972, op. cit. supra, p. 136.

106 Rawls, 1972, op. cit. supra, pp. 60, 83, 303; cf. pp. 250, 302, 303. 
Justice as fairness and its methodology of the original position lead first of all to principles of a just social order of individuals within a state. Application of the methodology of the original position to the international level, more specifically to the states parties to the Moon Treaty, must take into account two important differences. First, the subjects of justice are states, not individuals. Second, principles of justice are already given with the Moon Treaty. The problem now is not: how to arrive at fundamental principles, but: how to arrive at plausible specific notions of the general concepts of justice which are given in the provisions of the Moon Treaty.

Although Rawls does not elaborate the principles which would have to govern international society, he indicates, however, how the theory of justice, including the original position, could be extended to international society. As Rawls introduces the extended original position in the context of the justification of conscientious refusal, he conceives the original position as a meeting of representatives of nations who must choose together the fundamental principles to adjudicate conflicting claims among states. 107 The extended original position will be applied below to arrive at the basic principles which are to govern the distribution of benefits deriving from exploitation of the natural resources of the moon. In virtue of the provisions of the Moon Treaty on the future establishment of an international régime, the distribution of these benefits should be equitable. The states party to this treaty have to determine, in other words, what constitutes such equitable sharing. Rawls' original position might be a fruitful start.

The states party to the Moon Treaty will thus be imagined to determine the meaning of "equitable sharing" in a Rawlsian original position, which I will henceforth call the "international original position" to distinguish it from the original position which refers to national society.

The starting-point of the original position is the equality of the participants, an equality which can correspond at the international level with the formal equality of states. 108 As noted before, equality in the original position is expressed by the veil of ignorance. In the international original position it is the same:

"... I assume that these representatives are deprived of various kinds of information. While they know that they represent different nations each living under the normal circumstances of their own society, they know nothing about the particular circumstances of their own society, its power and strength in comparison with other nations, nor do they know their place in their own society. Once again the contracting parties, in

107 Rawls, 1972, op. cit. supra, p. 377 et seq.: Rawls uses the words "nation" and "state" indiscriminately.

108 Cf. Art. 2 par. 1 U.N. Charter; cf. also note 57. 
this case representatives of states, are allowed only enough knowledge to make a rational choice to protect their interests but not so much that the more fortunate among them can take advantage of their special situation. This original position is fair between nations; it nullifies the contingencies and biases of historical fate. Justice between states is determined by the principles that would be chosen in the original position so interpreted." 109

In addition to the information Rawls mentions as veiled, the representatives of states in the international original position neither know the size of the population they represent nor its level of well-being nor whether their respective countries possess natural resources. In this manner, the participants cannot identify themselves and thus lack any basis to bargain or to otherwise tailor principles to suit their interests110: "The arbitrariness of the world must be corrected for by adjusting the circumstances of the initial contractual situation." 111 It serves to counter the "ingeniously perfected techniques [of sovereign states in the international decisional process, $\mathrm{mz}$ ] to maximize their views of national interests and particularized well-being". 112

Although the participants in the original position are veiled, they are certainly not blinded. They know whatever general facts affect the choice of the principles on equitable sharing. 113 The participants, for instance, know that they represent a state and a population albeit its size and level of development are unknown to them. They are also aware - again without being able to identify either themselves or others as representatives of a particular state - of the existence of enormous differences in wealth between the various states in the

109 Rawls, 1972, op. cit. supra, p. 378; Note that this quotation emphasises the fact that Rawls' theory of justice looks to the future and is therefore not retributive in character.

110 Rawls, 1972, op. cit. supra, p. 139; cf. p. 140; cf. "If a knowledge of particulars is allowed, then the outcome is biased by arbitrary contingencies." (p. 141).

111 Rawls, 1972, op. cit. supra, p. 141 (emphasis added).

112 Pardo, A. / Christol, C. Q:, The Common Interest: Tension Between the Whole and the Parts, in Macdonald, R. St. J. / Johnston, D. M. (eds.), The Structure and Process of Intemational Law: Essays in Legal Philosophy, Doctrine and Theory, The Hague 1983, p. 652.

113 Rawls, 1972, op. cit. supra, p. 137; "It is taken for granted, however, that they know the general facts about human society. They understand political affairs and the principles of economic theory; they know the basis of social organization and the laws of human psychology. ... There are no limitations on general information, that is, on general laws and theories, since conceptions of justice must be adjusted to the characteristics of the systems of social cooperation which they are to regulate, and there is no reason to rule out these facts." (pp. 137, 138). 
world. ${ }^{114}$ They are bound to find an equitable key to divide the benefits which will arise from the exploitation of the moon in such a way that all mankind will benefit therefrom. 115

Thus the state-representatives in the international original position are in two ways restrained in reaching their conclusions on justice. First, they are subject to the normal conditions of the veil of ignorance, suitably qualified so as to be applicable to representatives of states. Second, they must take the principles already formulated in the Moon Treaty as their material starting-point. That second point constitutes an important difference with the original position in its "original" role, leading to the first principles of justice.

In their international original position, the state-representatives might arrive at the following guideline for distribution of the future benefits deriving from exploitation of the natural resources of the moon and other celestial bodies:

114 They know that the average income (expressed in GNP percapita) in the North is 18 times the average in the South, that there are 1.2 billion poor people in the developing countries, that in these countries 1.5 billion people still lack basic health care, that one-fifth of the population there still goes hungry every day and that more than 1 billion people still live in absolute poverty. Human Development Report, 1991, Published for the United Nations Development Programme, Oxford 1991, p. 23, 24. I take it that "living in absolute poverty" means within the terminology of this Report, below "the poverty line". The "poverty line" is defined as follows: "That income level below which a minimum nutritionally adequate diet plus essential non-food requirements are not affordable." (p. 195).

115 Cf. Dupuy, R. J., Conclusions in the light of the Notion of Mankind / on the workshop, in Dupuy, 1984, op. cit. supra: "Now, the juridical and institutional formation of the concept of mankind would suppose, for those concerned, that they [states, i.e., mz] no longer see things between them but in mankind" (p. 482). "This attitude is the negation of the international community - the present moment of mankind" (p. 485).

A question raised earlier with regard to the extension of mankind in time, the answer to which was deferred to the present paragraph, should now be answered. There are two conceivable ways to ensure that future generations will benefit from the exploitation of the moon's natural resources. First, it could be assumed that the participants in the intemational original position do not know which generation they do represent, so that whatever the temporal position of each participant, "each is forced to choose for everyone"; Rawls, 1972, op. cit. supra, p. 140. A second possibility, perhaps less far-fetched and complicated - i.e. if the participants are not thought of as contemporaries the knowledge as regards, for instance, technological possibilities for exploitation and the like cannot be assumed to be the same for each of them - is to view the participants as contemporaries, but to define "mankind" as in principle comprising more than one generation. Cf. art. 4 Moon Treaty; Joyner, C. C., Legal Implications of the Concept of the Common Heritage of Mankind, 35 Intemational and Comparative Law Quarterly (1986), p. 195; Gorove, 1977, op. cit. supra, p. 69; Wolfrum, $R$., The Principle of the Common Heritage of Mankind, 43 Zeitschrift für ausländisches und öffentliches Recht und Völkerrecht (1983), p. 318; Nagy, 1988, op. cit. supra, p. 319; Christol, 1980, op. cit. supra, p. 452. 
Benefits and burdens of the exploitation of the natural resources of the moon ought to be distributed in such ways that the position of the least advantaged states is likely to be improved.

As may be evident, parties in the original position will also further determine the distribution of benefits in relation to size of population and the like in order to do justice to the requirement of "mankind" as the ultimate beneficiary of the benefits deriving from exploitation of the natural resources referred to.

As noted before, persons in the original position do not know their actual positions in life. Thus their deliberations are in large part guided by their desire to avoid the unbearable position of the worst-off, be they individuals or states, as in this case. Analogous to the difference principle, see above, state-representatives will opt for principles which protect the less-well endowed among the states in the world.

This "difference principle among states" is considerably more specific than the principles laid down in the Moon Treaty. It leads to specification of two important notions in this treaty, viz. "equitable sharing according to the interests and needs of the developing countries" and "equitable sharing according to efforts in exploration". First, the notion of equity is central to the idea of the original position and its products, principles of justice, To achieve equity a procedure is introduced which includes several restrictions, in particular that of the veil of ignorance, to ensure, inter alia, the equality of the participants both as actors in the original position and as regards what they represent, so that the participants cannot identify themselves and subsequently use the identification to obtain a position tailored to it. Second, a specific interpretation is given to "interests and needs of developing countries" and to "efforts of these countries which have contributed ... to the exploration of the moon". Such efforts should be rewarded only in so far as they contribute to the position of the least well-off in international society. Although efforts will thus only be rewarded subject to the condition referred to, they may still lead to short-term advantages for the pioneer exploring countries, as their efforts are needed to trigger off actual future exploitation. In other words, the practical application of the provisions of the Moon Treaty is not only dependent upon principles but to a large extent upon facts as well.

Along the same lines of reasoning the requirement of rational management of the resources could be elaborated as well as the issues of the efficient ecploitation of the resources, the priority which should be assigned to preventing pollution in relation to exploitation and future voting procedures. 


\section{Solidarity vs. Rights-based Claims}

Two observations formed the incentives to apply the device of the original position, such as is developed by Rawls, at the international level. First, the application of the original position as an international original position illustrates how certain principles can be derived from the provisions of the Moon Treaty as premises. Principles which could figure as guidelines for the actual establishment of the régime which is to govern the exploitation of the natural resources of the moon and the subsequent distribution of the benefits accruing therefrom.

The classical counter-argument against arguments based on (social) contract that one cannot - logically - derive anything else from the premises than that which one put in them in the first place, fits in conveniently in this context, if one considers the fact that the premises used in the international original position are specific treaty obligations which the states parties to the treaty concerned have undertaken to apply in good faith.

The second motive for using a device like the international original position is that it shows more clearly than by just looking at the treaty obligations concerned the rights-basis of certain claims which are currently advanced by newly independent states on the basis of the concept of the common heritage of mankind.

The rights-character is particularly important to mark the contrast with charity and charitable acts. For certain western states the concept of the common heritage of mankind is considered to be merely another instrument of development aid.116 An important characteristic of development aid is that it is aid given on a voluntary basis by the donors without a legal obligation to do so. Consequently, the receivers of such aid cannot lay claims to the continuation or increase of such aid, how it is (to be) implemented 17 and more often than not, they are not in a position to pull strings attached to such aid.

The term solidarity rights which is frequently used to refer to the third generation rights (including the right to benefit from the common heritage of mankind) is a misnomer if one considers the connotation of noncommittal it carries which conceals and thus ignores the rights-character of the claims put forward and the corresponding obligations to which they

116 As regards the position - in the intemational law of the sea - that activities in the sea-bed area should be carried out for the benefit of all mankind, Wolf rum observes that the industrialized states (in particular the USA) concentrated on the aspect of preferential treatment: "However, they regarded those revenues as being part of development aid and denied any respective right of developing countries thereto." Wolfrum, 1983, op. cit. supra, p. 322.

$117 \mathrm{Cf}$. for the bizarre results to which westem aid to refugees in African countries leads, HarrellBond, B. E. Imposing Aid: Emergency Assistance to Refugees, Oxford 1986, see in particular pp. 13,14 and 15 . 
give rise. Solidarity implies sentiments which are clearly not the same as legal obligations to perform concrete acts. I don't mean to deny the hortatory power of solidarity as a source for the creation of new norms, but compared to a procedure such as the international original position, in which self-interest ultimately forms the basis of new and equitable obligations, self-interest seems a more reliable motive than solidarity. 118

\section{Conclusion}

First of all, a softening of the dichotomies between the first and second, and third and fourth generations which I introduced for the sake of developing the argument is needed. A classification into neat categories invariably entails loss of substance.

The categorization certainly does not intend to entail a conclusion to the effect that the first and second generations of human rights would be unconnected domains which are merely united in the subject they address: the national government. The rights of the two generations are clearly supplementary which already appears from the denominators of these two categories, formal respectively material equality. Only in conjunction will the rights of these generations accomplish a more humane and just society. 119

The same holds for the third and fourth generation rights which operate at the international level at which the states are addressees. For instance, peace is not merely the absence of war, which would only result in a nominal peace, but requires the international community to actively pursue conditions which are conducive to an atmosphere in which war is ultimately eliminated as the solvent of conflicts and in which conflicts are settled in a peaceful manner.120 Such an atmosphere is envisaged by the solidarity rights which I classified as fourth generation rights, which are to lead to a world wherein tensions caused by disparities in (economic) power and development and the like are eliminated.

$118 \mathrm{Cf}$. Alston's criticism on the notion of solidarity as a distinctive characteristic of third generation rights, 1982, op. cit. supra, pp. 318, 319; cf. Rawls, 1972, op. cit. supra; "They [the principles of justice for the basic structure of society, $\mathrm{mz}$ ] are the principles that free and rational persons concemed to further their own interests would accept in an initial position of equality as defining the fundamental terms of their association." (p. 11, emphasis added).

119 Cf. Flinterman, 1990, op. cit. supra, pp. 76, 77; cf., inter alia, U.N. G.A. Res. 32/130 Altemative approaches and ways and means within the United Nations system for improving the effective enjoyment of human rights and fundamental freedoms, of 16 December 1977.

120 Cf. Röling, 1960, op. cit. supra, pp. 51, 54; cf. also Tomuschat, 1985, op. cit. supra, p. 271. 
The argument equally does not entail a conclusion to the effect that third and fourth generation rights are prerequisites to the rights of the first and second generation. 121 As the first-mentioned generations do not at all establish rights of groups as against the individual, such a conclusion cannot even be deduced. An advantage of the categorization into four categories is that it shows that such an argument against third (and fourth) generation rights is not conclusive.

The division into categories equally does not entail a value judgment that each succeeding generation would be more evolved and sophisticated than its predecessor 122 , as each category operates in its own field and merely supplements the others.

The character of the various rights as human rights is neither questioned nor judged in this paper. The argument proceeded from the fact that so-called solidarity rights are currently advanced as human rights. Taking this as starting-point, the various rights were analyzed to demonstrate the character of the claims they embody. The introduction of a fourth category upon analyzing these various claims is without prejudice to the designation of these rights as human rights. Although I did not and will not judge the wisdom of this designation for all these claims, I do think it is quite understandable that they are introduced unter the heading of human rights as they all, both in first and final analysis, concern the basic wellbeing of individuals. 123 Although the third generation rights seem only to corroborate the foregoing to a lesser extent, the fourth generation right to share in the common heritage does show clearly its concern with individuals and in particular the well-being of these individuals by proceeding its claims on behalf of mankind, thereby explicitly surpassing the state as the primary and beneficiary actor. The qualification of solidarity rights as human rights is therefore not challenged and although the division of these solidarity rights in two categories, those of third and fourth generation rights, should not be understood too rigidly, it enabled to refute the criticism which is advanced against the solidarity rights in general, namely that these rights lack a precise object and consequently do not give rise to specific rights and obligations and cannot therefore be judicially enforced. From the analysis of the rights to peace, self-determination and natural resources emerged that the object and contents of the rights mentioned are not only clear but even well-established. The character of the obligations to which they give rise are all of a similar kind, in that they all demand abstention and non-interference from states. These obligations are enforceable just like any other inter-state obligation.

121 Cf. Kooijmans, P. H., Human Rights - Universal Panacea? Some reflections on the so-called human rights of the third generation, 37 Netherlands Intemational Law Review (1990), p. 329.

122 Alston, 1982, op. cit. supra, p. 316.

123 Cf. art. 28 of the Universal Declaration of Human Rights (adopted and proclaimed by G.A. Res. 217 A (III) of 10 December 1948): "Everyone is entitled to a social and intemational order in which the rights and freedoms set forth in this declaration can be fully realized." 
The - fourth generation - right to benefit from the common heritage of mankind is, compared to the three rights referred to above, different in character. The obligation to which this right compels is action from states, in particular it demands they establish certain pattems of distribution. By applying Rawls' theory to the provisions of the Moon Treaty, the meaning of the demand of an equitable distribution could be defined as well as the manner in which such distribution could take place. Other candidates for the fourth generation of human rights, which all concern issues of distribution, such as the right to development and the right to food, could also benefit from Rawls' method of the original position to define specific obligations for the states parties concerned.

However, for those who still consider the solidarity rights too vague, I would like to quote Professor Röling: "The adoption of vague standards marks a phase of transition. They indicate the direction in which the law is developing."124 I would like to add that the current direction appears to be one towards a more just international society.

124 Röling, 1960, op. cit. supra, p. 49; Röling, 1985, op. cit. supra, pp. 218, 219; cf. also Brunnée, 1989 , op. cit. supra, who refers to "the fact that intemational law is at a tuming point from a system balancing conflicting sovereign interests to one of constructive interaction for the common good." (p. 792). 


\section{Annex}

Diagram of the various generations of human rights

\begin{tabular}{|c|c|c|}
\hline Characteristics & $\begin{array}{l}\text { National Level } \\
\text { within states }\end{array}$ & $\begin{array}{l}\text { Intemational Level } \\
\text { between states }\end{array}$ \\
\hline & $\begin{array}{l}\text { First Generation Rights } \\
\text { (rights of the Political Covenant } \\
\text { and the internal right of self- } \\
\text { determination) }\end{array}$ & $\begin{array}{l}\text { Third Generation Rights } \\
\text { (extemal right of self- } \\
\text { determination, right to peace, } \\
\text { right to natural resources) }\end{array}$ \\
\hline \multirow[t]{2}{*}{$\begin{array}{l}\text { Abstention } \\
\text { Participation } \\
\text { Formal Equality }\end{array}$} & $\begin{array}{l}\text { by the state } \\
\text { of persons } \\
\text { of persons }\end{array}$ & $\begin{array}{l}\text { by states } \\
\text { of states } \\
\text { of states }\end{array}$ \\
\hline & $\begin{array}{l}\text { Second Generation Rights } \\
\text { (rights of the Social Covenant) }\end{array}$ & $\begin{array}{l}\text { Fourth Generation Rights } \\
\text { (right to share in the common } \\
\text { heritage of mankind, right to } \\
\text { development, right to food) }\end{array}$ \\
\hline Material equality* & of persons & of states (mankind) \\
\hline
\end{tabular}

* equal opportunities; redress of unequal initial positions; a certain level of well-being. 


\section{ABSTRACTS}

Return to the Constitution, Reform of the Constitution or Adoption of a New Constitution? - An Interim Report on the Democratic Reform of the Nationalist-Chinese Constitutional Law

\section{By Wolfgang Lasars}

In 1987, the martial law has been lifted in Taiwan and, as a result, a liberal and critical press developed as well as a political opposition party has been founded. This has led to further demands for fundamental democratic organizational reforms of constitutional bodies. The article begins with a description of the initial constitutional situation and its later transformation in Taiwan. Then, the constitutional discussion of the last years, the historical and political background, which burdens the discussion, and the great variety of legal ways proposed to overcome the constitutional crisis are examined. Finally, the actually taken, extremely cautious legal reform steps are analyzed, especially the Law of the Voluntary Retirement of the Old and Experienced Representatives of the First Central Representative Bodies, the Interpretation No. 261 by the Council of the Grand Justices and the Amendment to Constitution of 1991. The article concludes that democratic progress has been made, albeit without a democratic participation of the citizens. There are founded hopes that Taiwan will proceed on its way to democracy and to the rule of law and will complete its economical success, which made it one of the "four dragons" in Asia, by a similar political success.

The Concept of "Generations" of Human Rights and the Right to Benefit from the Common Heritage of Mankind with Reference to Extraterrestrial Realms

\section{By Marjoleine Y. A. Zieck}

The creation of a new category of human rights in the seventies with the name "third generation" or "solidarity" rights induced the renaming of the already existing rights - the civil and political rights on the one hand and the economic, social and cultural rights on the other hand - as the first respectively the second generation of human rights.

The new, third generation increasingly got the character of a residual category consisting of miscellaneous rights. The article attempts to analyze this residual category and the different 
claims it comprises by dividing it into two groups: a group which contains rights with an ordering function in the international society (these rights will be called third generation rights). The intemational order which is to ensue from the realization of these rights is one characterized by the formal equality of its constituent parts, the states. The second group (called the "fourth" generation) consists of claims which embody a concept of material equality. Both groups operate within the international community in contradistinction to the first two generations which have explicit functions within national societies.

The division of rights into four generations is based on the assumption that the rights of respectively the first and third generation are congenial and that a similar congeniality exists between the second and fourth generations.

Besides these parallels which are demonstrated in the article, one "fourth" generation right is analyzed, the right to benefit from the common heritage of mankind such as formulated with reference to outer space. In the Agreement governing the Activities of States on the Moon and other Celestial Bodies, the moon and its natural resources are declared to be the common heritage of mankind. The states parties to this treaty undertook to equitably share the benefits deriving from exploitation of the lunar common heritage. With help of John Rawls' theory of justice, in particular its device of the "original position", the meaning of such "equitable sharing" will be identified.

The analysis of the right to benefit from the common heritage of mankind is not only intended to exemplify the distinct character of the fourth generation but also to refute an important objection to solidarity rights in general, viz. that these rights lack a precise object and are thus incapable of producing definite obligations and as a consequence cannot be judicially enforced.

\section{Islamization of the Sudan Laws and Constitution: Its Allure and its Impracticability}

\section{By Akolda M.Tier}

Traditionally, Sharia (or Islamic religious) law is a personal law for Muslims in matters of the family and succession to property. Although this subject matter can be extended to other civil (i.e. non-criminal) matters through parties' choice of law and the quasi-legislative power of the civil (i.e. in the wider sense of non-Sharia) courts to decide, in the absence of legislation, according to "justice, equity and good conscience" or other similar phrase, no such extension occured. The transition of Sharia law from personal law of Muslims, for which it is peculiarly suited, to the unfamiliar area of territorial laws (i.e. laws which apply to all persons without distinction as the religion or ethnic community) and some aspects of the constitution was effected by the legislature. In 1980's, Islamic principles were incorporated by way of addition to, or repeal of, existing rules of criminal law 